\title{
REVIEW
}

\section{Environmental effects of increased atmospheric carbon dioxide}

\author{
Willie Soon ${ }^{1, *}$, Sallie L. Baliunas ${ }^{1}$, Arthur B. Robinson ${ }^{2}$, Zachary W. Robinson ${ }^{2}$ \\ ${ }^{1} \mathrm{H}$ arvard-Smithsonian C enter for A strophysics, $60 \mathrm{G}$ arden Street, C ambridge, M assachusetts 02138, USA \\ ${ }^{2}$ Oregon Institute of Science and Medicine, 2251 Dick George Road, C ave J unction, Oregon 97523, USA
}

\begin{abstract}
A review of the literature concerning the environmental consequences of increased levels of atmospheric carbon dioxide leads to the conclusion that increases during the 20th century have produced no deleterious effects upon global climate or temperature. Increased carbon dioxide has, however, markedly increased plant growth rates as inferred from numerous laboratory and field experiments. There is no clear evidence, nor unique attribution, of the global effects of anthropogenic $\mathrm{CO}_{2}$ on climate. Meaningful integrated assessments of the environmental impacts of anthropogenic $\mathrm{CO}_{2}$ are not yet possible because model estimates of global and regional climate changes on interannual, decadal and centennial time scales remain highly uncertain.
\end{abstract}

KEY WORDS: Global warming · Carbon dioxide · Atmospheric and biological effects

\section{INTRODUCTION}

Increases in minor greenhouse gases (GHGs) are hypothesized to cause large increases in surface and lower atmospheric temperatures on the basis of computer climate modeling, a branch of science still in its infancy despite recent substantial strides in knowledge. Their potential climatological impacts have been studied using a variety of computer simulations, from simple 1-dimensional models to complex 3-dimensional, coupled ocean-atmosphere general circulation models (GCMs). The credibility of the calculations rests on the validity of the models. The only way to evaluate the models is to compare their predictions of current and past conditions to available climate information and look for consistencies or inconsistencies with relevant, observed climate parameters, which ideally should be accurately measured. Although the models intrinsically have heuristic power, that fact does not guarantee accurate retrodiction and prediction. Hence, it is important to test the hypothesis that a significantly increased atmospheric $\mathrm{CO}_{2}$ causes significant global climatic warming and associated impacts.

*E-mail: wsoon@cfa.harvard.edu
We study 2 aspects of the consequences, realized and potential, of increased and increasing atmospheric $\mathrm{CO}_{2}{ }^{1}$ One is the climatic response to increases in atmospheric $\mathrm{CO}_{2}$ concentration; the other is the response of plants to increases in the air's $\mathrm{CO}_{2}$ content. We review aspects of observed climatic parameters and compare them to retrodictions of the climate models. Our purpose is to assess the credibility of the models by comparing model outcomes to real-world observations. The parameter selection we use is hardly exhaustive, and focuses on parameters that highlight the weaknesses of the models, from which progress might be made. In particular, we chose global and regional surface and lower tropospheric temperatures, regional storms (i.e. Atlantic hurricanes, as a representation of the ocean-atmosphere interaction) and sea level change (because it is coupled to temperature changes through sea-ice interaction). We also discuss early attempts to integrate the highly complex climatic

\footnotetext{
${ }^{1}$ For the purposes of discussion in this paper, we will use carbon dioxide as a surrogate for itself and the other minor GHGs that have been associated with the global warming hypothesis. Greenhouse warming models usually assume that the input of all the minor GHGs produces an effect roughly twice that of $\mathrm{CO}_{2}$ alone
} 


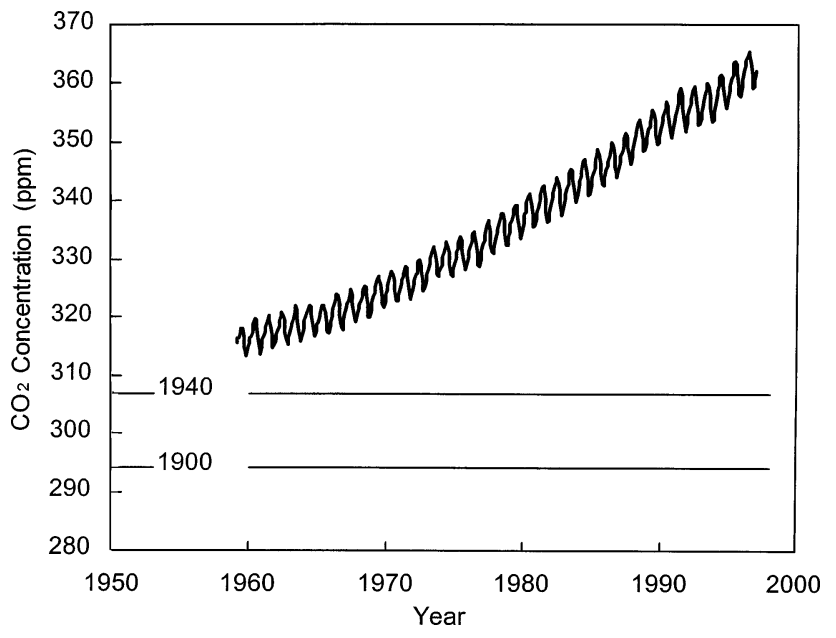

Fig. 1. Atmospheric $\mathrm{CO}_{2}$ concentration in parts per million by volume (ppm) at M auna Loa, Hawaii (Keeling \& Whorf 1997). The approximate global levels of atmospheric $\mathrm{CO}_{2}$ in 1900 and 1940 are also displayed (Idso 1989)

feedbacks associated with the biosphere into general circulation models (e.g. Henderson-Sellers et al. 1996).

The second main consequence of increased atmospheric $\mathrm{CO}_{2}$ that we discuss is the hypothesis that plant growth is enhanced under high $\mathrm{CO}_{2}$ concentrations, i.e. that elevated atmospheric $\mathrm{CO}_{2}$ concentrations increase plant growth rates, biomass and yield. This hypothesis is tested against experimental laboratory and field results; again, rather than be exhaustive, we show a few specific examples of vegetation responses to increased atmospheric $\mathrm{CO}_{2}$.

\section{ATM OSPHERIC CARBON DIOXIDE}

The concentration of $\mathrm{CO}_{2}$ in Earth's atmosphere has increased during the past century, as shown in Fig. 1 (Keeling \& Whorf 1997). Solid horizontal lines show the levels that prevailed in 1900 and 1940 (Idso 1989). The magnitude of this atmospheric increase during the 1980s was about 3 gigatons of carbon (Gt C) per year. Total annual human $\mathrm{CO}_{2}$ emissions-primarily from the use of coal, oil, natural gas and the production of cementestimated for 1996 are $6.52 \mathrm{Gt} \mathrm{C}$ (M arland et al. 1999).

To put these values in perspective, it is estimated that the atmosphere contains $750 \mathrm{Gt} \mathrm{C}$; the surface ocean contains $1000 \mathrm{Gt} \mathrm{C}$; vegetation, soils, and detritus contain $2200 \mathrm{Gt} \mathrm{C}$; and the intermediate and deep oceans contain $38000 \mathrm{Gt} \mathrm{C}$. Each year, the surface ocean and atmosphere exchange an estimated $90 \mathrm{GtC}$; vegetation and the atmosphere, $60 \mathrm{Gt} \mathrm{C}$; the marine biota and the surface ocean, $50 \mathrm{Gt} \mathrm{C}$; and the surface ocean and the intermediate and deep oceans, $100 \mathrm{GtC}$ (Schimel 1995).
So great are the magnitudes of these reservoirs, the rates of exchange between them, and the uncertainties with which these numbers are estimated, that the source of the recent rise in atmospheric $\mathrm{CO}_{2}$ has not been determined with certainty (e.g. Houghton et al. 1998, Keeling et al. 1998, Peng et al. 1998, Segalstad 1998). A tmospheric concentrations of $\mathrm{CO}_{2}$ are reported to have varied widely over geologic time, with peaks, according to some estimates, some 20 -fold higher than at present and troughs at approximately 18th century levels (Berner 1997).

There is, however, a widely believed hypothesis that

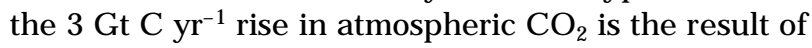
the release of $\mathrm{CO}_{2}$ from human activities. This hypothesis is reasonable, since the magnitudes of human release and atmospheric rise are comparable, and the atmospheric rise has occurred contemporaneously with the increase in production of $\mathrm{CO}_{2}$ from human activities since the Industrial Revolution. Atmospheric $\mathrm{CO}_{2}$ levels have increased substantially during the past century, and are expected to continue to do so.

However, the factors that influence the atmospheric $\mathrm{CO}_{2}$ concentration are not fully understood. For example, the current increase in $\mathrm{CO}_{2}$ follows a $300 \mathrm{yr}$ warming trend, during which surface and atmospheric temperatures have been recovering from the global chill of the Little Ice Age (see below). The observed increases in the atmospheric concentration of $\mathrm{CO}_{2}$ are of a magnitude that can, for example, be explained by oceans giving off gases naturally as temperatures rise (Dettinger \& Ghil 1998, Segalstad 1998). Indeed, changes in atmospheric $\mathrm{CO}_{2}$ have shown a tendency to follow rather than lead global temperature changes (Kuo et al. 1990, Priem 1997, Dettinger \& Ghil 1998, Fischer et al. 1999, Indermühle et al. 1999). Those studies emphasize the need to understand changes in terrestrial biomass and sea surface temperature, 2 important drivers of change in atmospheric $\mathrm{CO}_{2}$ concentration. Thus, understanding the carbon budget is a prerequisite for estimating future atmospheric $\mathrm{CO}_{2}$ concentration scenarios.

\section{ATM OSPHERIC AND SURFACE TEM PERATURES}

What effect is the ongoing rise in the air's $\mathrm{CO}_{2}$ content having upon global temperature? In order to answer this question, one must consider the available temperature information and its qualifications. The temperature of the Earth varies naturally over a wide range, but available temperature records are spatially and temporally limited. Records going back longer than $350 \mathrm{yr}$ are reconstructed from proxies. A recent reconstruction of northern hemisphere temperature from several sites yields a record going back $1000 \mathrm{yr}$ 
(Mann et al. 1999). That reconstruction is based primarily on tree ring width and density, which are primarily indicators of summer temperature. The record has varied over a range of no more than $1^{\circ} \mathrm{C}$ in the hemispheric average. There are important limitations to the interpretation of the proxy temperature. For example, Briffa et al. (1998) find tree width and density have become less sensitive to recent changes in temperature (see their Fig. 6) over the last few decades.

Going back further means having less global information. Fig. 2, for example, summarizes sea surface temperature reconstructed from oxygen isotopes in the shells of Globigerinoides ruber in sedimentary deposits in the Sargasso Sea during the past $3000 \mathrm{yr}$ (Keigwin 1996). Sea surface temperatures at this location have varied over a range of about $3.6^{\circ} \mathrm{C}$ during the past $3000 \mathrm{yr}$.

Both Mann et al.'s (1999) more widely sampled and Keigwin's (1996) local reconstructions display a longterm cooling trend that ends late in the 19th century. Two noticeable features in the Keigwin record are the Little Ice Age about $300 \mathrm{yr}$ ago and the Medieval Climate Optimum about $1000 \mathrm{yr}$ ago. During the M edieval Climate Optimum, temperatures were warm enough to allow the colonization of Greenland. The colonies were abandoned after the onset of colder temperatures, however, and for the past $300 \mathrm{yr}$, world temperatures have been gradually recovering (Lamb 1982, Grove 1996). According to Grove (1996), the glacial record maintains significant and coherent cooling over all continents, in agreement with the Bradley \& J ones (1993) reconstruction for the Northern Hemisphere. Thus, the evidence is that the Little Ice Age was at least a hemispheric-scale, if not global-scale, event. On the matter of the Medieval Climate Optimum, several lines of evidence point to warm temperatures roughly around 1000 yr BP (before present). The evidence

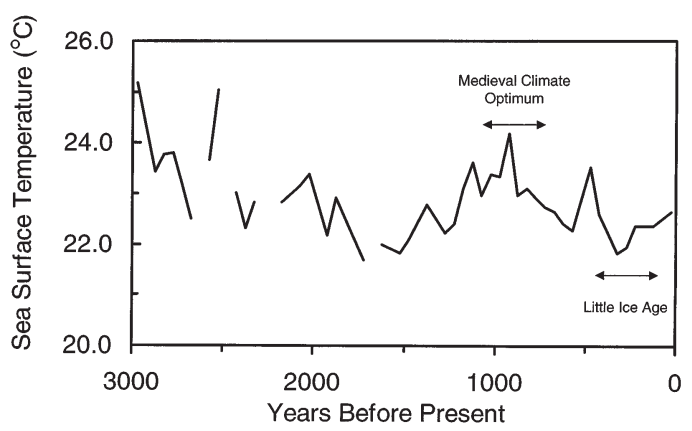

Fig. 2. Surface temperatures in the Sargasso Sea (with a time resolution of about $50 \mathrm{yr}$ ) over approximately $3000 \mathrm{yr}$ (ending in 1975), as determined by oxygen isotope ratios of marine organism (Globigerinoides ruber) remains in sediment at the bottom of the sea (Keigwin 1996). The Little Ice Age and Medieval Climate Optimum are indicated

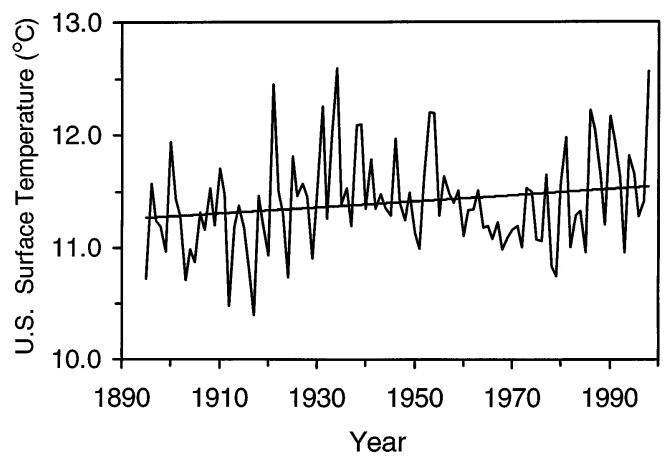

Fig. 3. Annual mean surface temperatures in the continental United States between 1895 and 1998, as compiled by the National Climate Data Center (Brown \& Heim 1998). The trend line for the entire data set with slope of $+0.027^{\circ} \mathrm{C}$ decade $^{-1}$ is indicated

includes montane glaciers, glacial moraines, tree ring and width growth, shell sediments and historical documentation, indicating fairly widespread, although not strongly synchronized, warmth. For example, in China and J apan the warming ended by $900 \mathrm{yr} \mathrm{BP}$, while in Europe and North America the warming continued for 2 or 3 more centuries (Lamb 1982, Grove \& Switsur 1994, Hughes \& Diaz 1994, Keigwin 1996, Grove 1996). The decreasing trend in reconstructed temperature of the northern hemisphere ( $M$ ann et al. 1999) is consistent with the erosion in climate on hemispheric scales, from $1000 \mathrm{yr}$ BP through the Little Ice Age.

In more recent times, instrumental records have become available. One long surface record with good quality control and coverage of a significant land area is that of the continental United States. Fig. 3 shows the annual average temperature of the United States as compiled by the National Climate Data Center (Brown $\&$ Heim 1998). The upward temperature fluctuation between 1900 and 1940 is natural and likely a recovery from the Little Ice Age. The United States temperatures show a non-significant increasing trend of $+0.027^{\circ} \mathrm{C}$ decade $^{-1}$. $^{2}$

\footnotetext{
${ }^{2}$ In several places in this review, we report linear leastsquares calculated trend lines for measurement compilations of temperatures, storm activity, and sea levels. Variability analyses for these compilations are reported in the referenced literature. Quantitative error estimations for the trend values are beyond the scope of this review. Systematic errors such as temporal or spatial limitations of the data and nonrandom fluctuations in underlying natural phenomena introduce substantial complications and uncertainty into such estimations. The calculated trend values are, however, helpful in understanding the graphically displayed observational results - which have been reproduced in the figures at resolutions that provide readily apparent representations of variability
} 


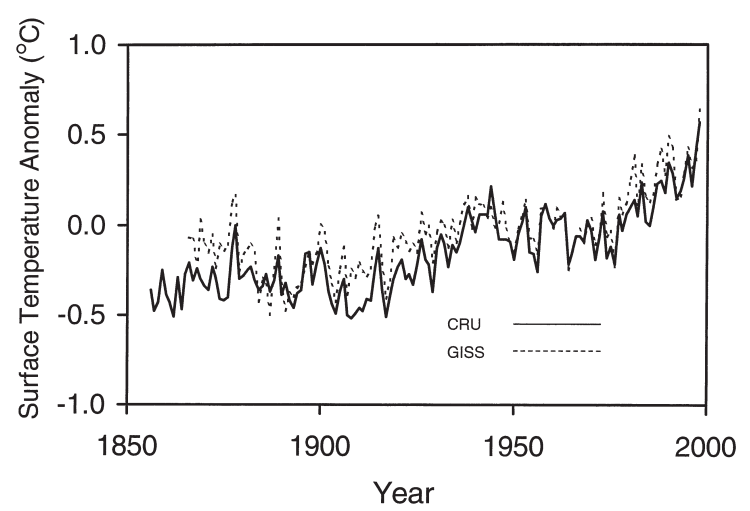

Fig. 4. Annual mean global surface temperature anomalies for land and sea-surface (solid), as reconstructed by CRU (Parker et al. 1994, CRU 1999), and for land only (dashed), as estimated by NASA-GISS (Hansen \& Lebedeff 1987, 1988, Hansen et al. 1996). An adjustment has been made for urban warming effects in both the CRU and GISS reconstructions

Surface temperature records compiled from worldwide stations by NASA-GISS (Goddard Institute for Space Studies; Hansen \& Lebedeff 1987, 1988, Hansen et al. 1996) and the Climate Research Unit (CRU) at the University of East Anglia, UK (Parker et al. 1994, CRU 1999) are shown in Fig. 4. The overall rise of about 0.5 to $0.6^{\circ} \mathrm{C}$ during the 20th century is often cited in support of greenhouse global warming (e.g. Schneider 1994). However, since approximately $80 \%$ of the $\mathrm{CO}_{2}$ rise during the 20th century (see Fig. 1) occurred after the initial major rise in temperature, the $\mathrm{CO}_{2}$ increase cannot have caused the bulk of the past century's temperature increase. In addition, it has been pointed out that reported increases in global and northern hemisphere surface temperatures since the 1970s have occurred mostly during cold seasons. The winter warming may be interpreted as natural dynamical variability owing to anomalous atmospheric circulation. The cause of circulation anomalies in the 1970s is a strong positive bias in the distinctive cold-ocean warm-land (COWL) pattern seen in the spatial distribution of the surface temperature records (Wallace et al. 1995, 1996). Could the increase in well-mixed $\mathrm{CO}_{2}$ gas in the atmosphere produce the observed regional changes in the COWL pattern? Results from GCM s are inconclusive; Broccoli et al. (1998) suggest that separating the COWL pattern from the hypothesized anthropogenic $\mathrm{CO}_{2}$ fingerprint is not straightforward (see further discussion below). Because a COWL pattern arises primarily from the differential thermal inertia contrast between the land and the sea, such an internal spatial pattern may be caused by any number of external warming influences (see also Corti et al. 1999).

Before interpreting other climate change patterns, the limitations of observed spatial and temporal trends should be examined. In terms of spatial cover- age, the surface records are limited because they are not truly global (e.g. Robeson 1995). The 0.5 to $0.6^{\circ} \mathrm{C}$ century ${ }^{-1}$ temperature trend for the last $100 \mathrm{yr}$ has been determined with uncertainties estimated to be smaller than the magnitude of the increase (Karl et al. 1994), despite the incomplete surface coverage. But serious uncertainty in uneven temporal sampling exists and it can come from 2 sources. One is the unknown time of day of observation, e.g. in cases where only monthly data have been given (Madden et al. 1993). A second source of temporal sampling error is gaps in records (Stooksbury et al. 1999), which in turn can bias spatial coverage through the rejection of a location whose period of measurement is incomplete. For example, in the $100 \mathrm{yr}$ period 1897 to 1996, M ichaels et al. (1998) found that imposing the validity requirement that data within $5^{\circ} \times 5^{\circ}$ gridded spatial cells should have no more than $10 \mathrm{yr}$ ( $10 \%$ of the period) of measurements missing produced a 'global' sample covering only $18.4 \%$ of the earth. This is not an optimal spatial coverage for determining a global mean. Jones et al. (1997) have attempted to address the influence of incomplete spatial sampling on the uncertainty in estimating global mean surface temperature by using several GCMs.

A further uncertainty in surface temperature measurements is the urban heat island bias. Fig. 5 shows the size of the urban heat island effect in measurements from surface stations in California. The results from all counties and selected sites in Fig. 5 should be compared with the results from the East Park station, considered the best situated rural station in the state (Goodridge pers. comm. 1998), which has a calculated temperature trend between 1940 and 1996 of $-0.055^{\circ} \mathrm{C}$ decade $^{-1}$. The urban heat bias has also been observed elsewhere (Balling 1992, Böhm 1998). Gallo et al. (1999) caution that the designations of surface temperature stations as urban, suburban, or rural need to be reassessed periodically because the current methodology can introduce bias in global and regional trends of surface temperatures.

The systematic error of the urban heat island effect has been extensively studied and debated, and remains controversial. For example, a recent analysis of rural and urban stations found no significant difference introduced into the calculated global trend by the urban stations until 1990 or so (Peterson et al. 1999). After 1990, the urban stations contributed a warming bias to the global average which is not seen in the rural stations. Peterson et al. (1999) note that rural station coverage has fallen from over $20 \%$ of the earth's area in the 1970 s to $7 \%$ in 1998 , which may explain the recent difference in trends between urban and rural temperatures, and also may introduce uncertainty in the global average. 


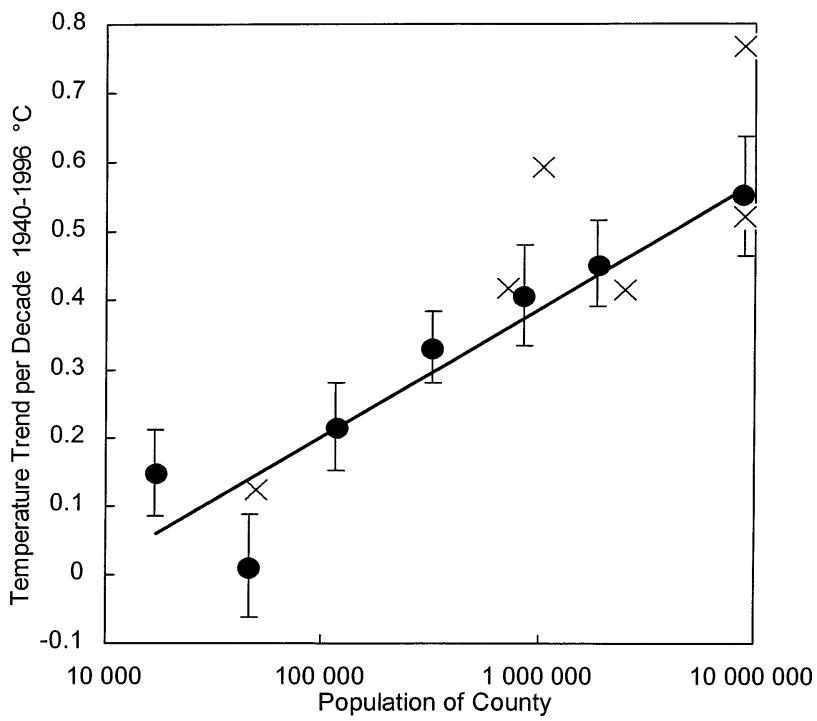

Fig. 5. Surface temperature trends for the period 1940 to 1996 from 107 measuring stations in 49 California counties (Christy \& Goodridge 1995, Goodridge 1996). After averaging the means of the trends in each county, counties of similar population were combined and plotted as filled circles along with the standard errors of their means. The 6 measuring stations in Los Angeles County were used to calculate the standard error of that county, which is plotted alone at the county population of 8.9 million. The urban heat island effect on surface measurements is evident. The straight line is a least-squares fit to the filled circles. $(X)$ The 6 unadjusted station records selected by NASA-GISS for use in their estimate of global temperatures as shown in Fig. 4

With the advent of the rapid growth rate in atmospheric $\mathrm{CO}_{2}$ concentration, attention has focused on the measurement of temperature trends of the last several decades. The uncertainties on decadal time scales in the surface record may be roughly comparable to the magnitude of the trend expected (Karl et al. 1994). However, tropospheric records can also be considered. Although the tropospheric measurements differ from the surface measurements, and are also relatively short, they are important in examining the effect of increases in the atmospheric concentration of $\mathrm{CO}_{2}$. In the troposphere, GHG-induced temperature changes are expected to be at least as large as at the surface (e.g. Houghton et al. 1996).

We consider 2 tropospheric records-from satellite and balloon platforms. Since 1979, essentially global lower-tropospheric temperature measurements have been made by means of Microwave Sounding Units (MSUs) on orbiting satellites (Spencer et al. 1990). Fig. 6. shows the average global tropospheric satellite measurements (Spencer \& Christy 1990, Christy et al. 1998). The tropospheric record can be extended back to 1958 with radiosonde data (Fig. 7, Angell 1997, pers. com. 1999 [data of Angell 1997 updated to February 1999]). The globally gridded radiosonde data on tro-

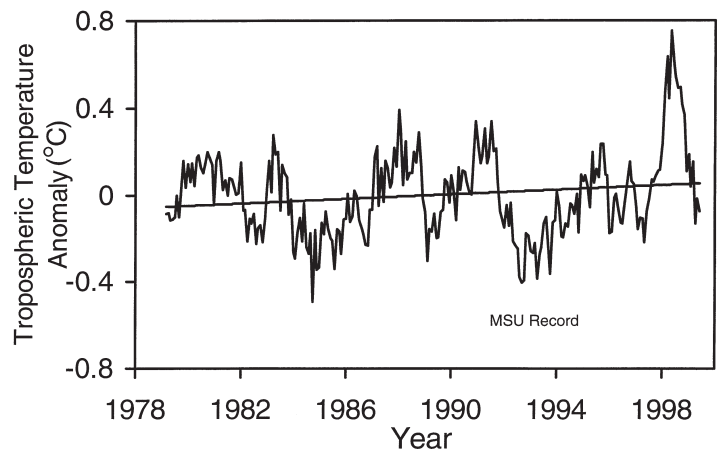

Fig. 6. Satellite Microwave Sounding Unit (MSU) measurements of global lower tropospheric temperatures between $82^{\circ} \mathrm{N}$ and $82^{\circ} \mathrm{S}$ from 1979 to $\mathrm{M}$ ay 1999 (Spencer \& Christy 1990, Christy et al. 1998). Temperatures are monthly averages and the linear trend for 1979 to $\mathrm{M}$ ay 1999 is shown. The slope of this line is $+0.054^{\circ} \mathrm{C}$ decade $^{-1}$

pospheric temperature (Parker et al. 1997) are also consistent with the satellite and Angell radiosonde tropospheric temperatures, although the interannual variance is slightly smaller in the Parker et al. (1997) data (not shown here). The agreement of the independent sets of data between 1979 and 1998 verifies their precision. Further agreement between balloon and satellite records has been shown rigorously by extensive analysis (Spencer \& Christy 1992, Christy 1995). An analysis of the satellite record (Wentz \& Schabel 1998) had pointed out a potential error in the calculated trend in the MSU measurements of the tropospheric temperature. The authors claimed that decay of the orbits of the individual satellites contributed to the records and made spurious trends in the data. However, the estimated uncertainty was exaggerated. The effect of orbital decay, when properly computed, and an additional effect, that of drift in the satellite orbit, have now

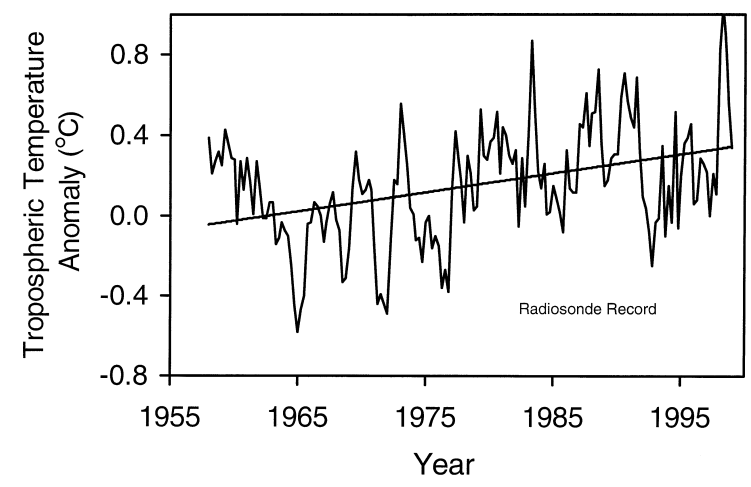

Fig. 7. Radiosonde balloon station measurements of lower tropospheric temperatures at 63 stations between $90^{\circ} \mathrm{N}$ and 90 ${ }^{\circ} \mathrm{S}$ from 1958 to February 1999 (Angell 1997, pers. comm. 1999 [data of Angell 1997 updated to February 1999]). Temperatures are 3 mo averages and the linear trend for 1958 to February 1999 is shown. The slope is $+0.095^{\circ} \mathrm{C}$ decade $^{-1}$ 
been applied to the MSU data (Christy et al. 1998). Those corrected data are the ones plotted in Fig. 6.

Tropospheric temperatures have shown a global trend of $+0.054^{\circ} \mathrm{C}$ decade $^{-1}$ (MSU, 1979 to May 1999) or $+0.018^{\circ} \mathrm{C}$ decade $^{-1}$ (radiosonde, 1979 to February 1999). Going back further, the trend in the tropospheric temperatures measured by radiosonde is $+0.095^{\circ} \mathrm{C}$ decade $^{-1}$ (1958 to February 1999 ). The physical significance of the tropospheric trends is difficult to assess. These periods are relatively short intervals over which to give interpretation to a trend because of large interannual variability (e.g. caused by the effects of ENSO and volcanic eruptions). But Christy \& McNider (1994, and updates in Christy 1997) had shown that even after the crude removal of the ENSO and volcanic effects, the adjusted MSU tropospheric global temperature $20 \mathrm{yr}$ trend can only be marginally consistent with the projected warming rates of 0.08 to $0.30^{\circ} \mathrm{C}$ decade $^{-1}$ by GCM simulations that included effects owing to $\mathrm{CO}_{2}$ (only) and tropospheric sulfate aerosol (direct effect only) over the last $20 \mathrm{yr}$ (Houghton et al. 1996, p. 438).

The tropospheric temperature trends can be compared to the trend in the CRU surface temperature records of $+0.11^{\circ} \mathrm{C}$ decade $^{-1}$ (1958 to 1998) and $+0.19^{\circ} \mathrm{C}_{\text {decade }^{-1}}$ (1979 to 1998). The surface trends are apparently significant, but are not consistent with the tropospheric trends. No clear resolution of this important discrepancy is at hand. However, in addition to uncertainties in the surface measurements, there are physical reasons for differences expected in the surface and tropospheric temperature trends as, for example, for the equatorial oceans (Trenberth et al. 1992, Christy 1995). (See discussion on the complications of attributing causes to recent climate change, below.) New attempts, post-Houghton et al. (1996), like Bengtsson et al. (1999) have further highlighted the inconsistency between the differing observed surfacetroposphere trends and the simulated GCM trends which try to include forcing factors like anthropogenic GHGs, tropospheric sulfate aerosols (both the direct and indirect effects), stratospheric aerosols from Mount Pinatubo, and tropospheric and stratospheric ozones.

Another useful record is that of stratospheric temperatures, which have been measured by MSUs since 1979 , and by balloon, although with less area and altitude coverage than for the satellite record, since 1958. The lower stratosphere (about $100 \mathrm{mb}$ ) has shown a significant cooling trend of about 0.6 to $0.7^{\circ} \mathrm{C}$ decade $^{-1}$ since 1979 (see e.g. Angell 1997, Parker et al. 1997, Simmons et al. 1999). Qualitatively, the cooling trend is apparently consistent with the expectation of cooling caused by increased radiative emission as a consequence of increased stratospheric $\mathrm{CO}_{2}$ concentration.
However, determination of the potential $\mathrm{CO}_{2}$ component of stratospheric cooling is ambiguous because the effects of volcanic aerosols, changes in stratospheric ozone and changes in solar ultraviolet forcing are also significant. These 3 effects can change with time and cannot be removed with precision. The frustration associated with the attribution of causes connected to lower stratospheric cooling, as well as variations of the surface and tropospheric temperatures, is discussed further below.

\section{MODELLED EFFECTS OF INCREASED ATMOSPHERIC $\mathrm{CO}_{2}$}

Incoming broadband solar radiation is, on average, approximately balanced by the outgoing thermal radiation of the earth. The major $\mathrm{GHG}, \mathrm{H}_{2} \mathrm{O}$ (in vapor forms), and minor GHGs like $\mathrm{CO}_{2}, \mathrm{CH}_{4}$ and $\mathrm{N}_{2} \mathrm{O}$ act to regulate this radiational balance by absorbing and reemitting large portions of the outgoing infrared terrestrial radiation. Introduction of additional $\mathrm{CO}_{2}$ into the atmosphere can be considered as an effective increase in radiative energy input to the Earth because of the increasing infrared opacity of the atmosphere. The heat is redistributed, both vertically and horizontally, by various physical processes, including advection, convection, and diffusion, in the atmosphere and ocean system.

When $\mathrm{CO}_{2}$ increases the infrared opacity of the atmosphere, how does the atmosphere respond? The radiative contribution of doubling atmospheric $\mathrm{CO}_{2}$ alone is not large, but the total response depends on many feedback mechanisms. This is the key issue. The computed response differs among the models because many of the physical processes are only rudimentarily understood and are variously parameterized. The essence of such a problem of climate models is documented in a study which showed that differences in the inter-model atmospheric responses on interannual time scales, e.g. to a common sea surface temperature forcing, are somewhat greater than ensemble responses obtained from intrinsic variability for a single model (e.g. Boyle 1998). The climate is a coupled, nonlinear dynamical system. The computer climate models have substantial uncertainties (Mason 1995). Without experimental validation of the models, the calculation of the climate response to increased anthropogenic atmospheric $\mathrm{CO}_{2}$ is not reliable. Also needed is a reliable calculation of the natural variability of the climate.

We discuss 6 important areas in climate modeling. First, nearly all models have substantial flux errors for which artificial flux adjustments are introduced. Systematic surface-ocean heat flux errors of up to $100 \mathrm{~W}$ $\mathrm{m}^{-2}$ are locally introduced into the calculations 
(Glecker et al. 1995, Murphy 1995, Glecker \& Weare 1997). One important consequence of such flux adjustments is to damp low-frequency variability in the simulation of a climate state through excessive overstabilization (Palmer 1999). A nother critical consequence of the artificial flux tuning is to introduce systematic biases in the model's estimates for important parameters of the climate system, such as annual mean and annual cycle amplitude of the equator-to-pole temperature gradient and the ocean-land surface temperature contrast ( ain et al. 1999). Several coupled oceanatmosphere models attempt to avoid flux adjustments. However, those models still show substantial climate drift and bias (Cai \& Gordon 1999, Yu \& Mechoso 1999).

In addition, results from the cooperative CAGEX ${ }^{3}$ and GEBA ${ }^{4}$ experiments, as well as the latest $\mathrm{ARESE}^{5}$ experiments (e.g. Wild et al. 1995, Charlock \& Alberta 1996, Valero et al. 1997a, Zender et al. 1997), show that there is atmospheric absorption unaccounted for by the present atmospheric radiation codes generally used in GCMs. Those observations suggest that the missing energy flux, when averaged over the whole globe, amounts to $25 \mathrm{~W} \mathrm{~m}^{-2}$ (Cess et al. 1995, Li et al. 1997) or 17 to $20 \mathrm{~W} \mathrm{~m}^{-2}$ (M. H. Zhang et al. 1998) or 10 to $20 \mathrm{~W}$ $\mathrm{m}^{-2}$ (Wild et al. 1998). The missing energy flux, interpreted as excess cloud absorption, occurs in both visible ( 224 to $680 \mathrm{~nm}$ ) and near-infrared (680 to $3300 \mathrm{~nm}$ ) wavelengths, while an excess absorption around $500 \mathrm{~nm}$ (with $10 \mathrm{~nm}$ bandwidth) can be ruled out (Valero et al. 1997b, Cess et al. 1999). The flux uncertainties are large compared to the expected forcing from doubling $\mathrm{CO}_{2},-4 \mathrm{~W} \mathrm{~m}^{-2}$ globally.

A second important factor in climate modeling is the understanding of water vapor feedback. The underlying process starts with increasing temperature that increases atmospheric water vapor concentration. The models assume that the water vapor is then distributed, especially to the middle and upper troposphere, in such a way as to globally increase water vapor content. Consequently, the enhanced water vapor would amplify the warming caused by increased $\mathrm{CO}_{2}$ alone. This is the dominant gain in the models for amplifying the effect of $\mathrm{CO}_{2}$ increases. This mechanism has been studied theoretically and observationally. Some evi-

${ }^{3}$ CAGEX - CERES/ARM/GEWEX - NASA's Clouds and the Earth's Radiation Energy System (CERES); Department of Energy's Atmospheric Radiation Measurement (ARM); World Climate Research Program's G lobal Energy and Water Cycle Experiment (GEWEX)

${ }^{4}$ World Climate Research Program's Global Energy Balance Archive (GEBA)

5Departments of Energy and Defense and NASA's Atmospheric Radiation Measurements Enhanced Shortwave Experiment (ARESE) dence supports a positive water vapor feedback (Liao \& Rind 1997, Soden 1997, Inamdar \& Ramanathan 1998). However, the model parameterization of the mechanism has been criticized (Renno et al. 1994, Spencer \& Braswell 1997). For example, the interannual variations of water vapor and temperature in the tropical troposphere have been shown to be too strongly coupled in a GCM when compared to observed relationships (Sun \& Held 1996). A comparison of observed decadal mean tropospheric precipitable water over North America, the Pacific basin and the globe with results from 28 GCMs revealed that simulated values are less moist than the real atmosphere for all 3 areas (Gaffen et al. 1997). Tropospheric moisture and convective transport processes are both spatially and temporally scale-specific (Hu \& Liu 1998, Yang \& Tung 1998). Without adequate observations, it is difficult to determine the correct parameterization of the $\mathrm{CO}_{2}$-induced water vapor feedback effect. Limited observations of precipitable water have been obtained in the tropics $\left(30^{\circ} \mathrm{N}\right.$ to $\left.30^{\circ} \mathrm{S}\right)$ and yield an indication of widespread drying of the upper troposphere between 1979 and 1995 (Schroeder \& M cGuirk 1998a; see also the exchange between Ross \& Gaffen 1998 and Schroeder \& McGuirk 1998b).

A third factor limiting model performance is uncertainty related to cloud forcing. Necessary observations of cloud properties are incomplete, although current intensive programs are progressing (Rossow \& Cairns 1995, Hahn et al. 1996, Weare 1999, Wylie \& Menzel 1999). In general, GCMs overpredict the coverage (cloudiness) of high clouds by a factor as large as 2 to 5 (Weare \& AMIP Modeling Groups 1996). For low clouds, models present a global average coverage that is 10 to $20 \%$ less than observed. Spatially, the modeled cloud distribution is also incorrect (Weare \& AMIP Modeling Groups 1996, Cess et al. 1997). The magnitude of such systematic errors in cloud parameterization is not negligible. Additional physical processes like the detrainment temperature-cirrus cloud feedback (Chou \& Neelin 1999) and the impact of clouds on the spectral distribution of incident irradiance (Siegel et al. 1999) should also be included. Therefore, the parameterization of radiative, latent and convective effects of cloud forcing needs further improvements (Fowler \& Randall 1999, Rotstayn 1999, Senior 1999, Yao \& Del Genio 1999).

A fourth critical area of uncertainty concerns the parameterization of the ocean-atmosphere interaction. The physics of the air-sea interaction is actively being studied, especially over the tropical oceans, with in situ and satellite observations of heat, momentum and freshwater fluxes. Observations of such parameters should improve our understanding of air-sea coupling (e.g. Godfrey et al. 1998). 


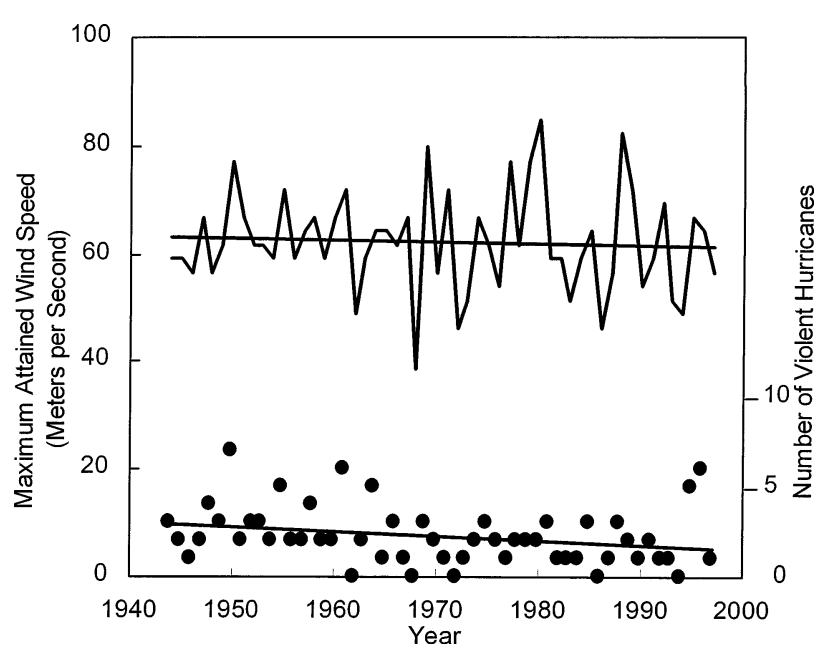

Fig. 8. Annual numbers of violent Atlantic Ocean hurricanes (bottom of panel) and their maximum attained wind speeds (top of panel) (Landsea et al. 1996). Slopes of the trend lines are -0.25 hurricanes decade ${ }^{-1}$ and $-0.33 \mathrm{~m} \mathrm{~s}^{-1}$ maximum attained wind speed per decade

As just one example of current model inadequencies in this area, we consider hurricanes and storms. Modeling storms is complex, one reason being that storms occur on spatially fine-scale fronts, below the resolution of most models (e.g. Hendersen-Sellers et al. 1998). One model result for roughly doubling atmospheric $\mathrm{CO}_{2}$ concentration calls for hurricane wind speeds to increase 3 to $7 \mathrm{~m} \mathrm{~s}^{-1}$ and for central surface pressures to drop by 7 to $20 \mathrm{mb}$ over the Western Pacific (Knutson et al. 1998). Another model predicts increases in precipitation extremes almost everywhere under the scenario of doubled atmospheric $\mathrm{CO}_{2}$ concentration (Zwiers \& Kharin 1998). Both studies admit to significant imprecision arising from uncertainties in the air-sea interaction and other model deficiencies like inadequate spatial resolution.

In testing these various predictions, storm assessment is possible in regions of the Atlantic where data go back 100 yr or so. Fig. 8 shows the number of severe tropical Atlantic hurricanes per year and also the maximum wind intensities of those hurricanes (Landsea et al. 1996). Both of these parameters have been decreasing with time. A nother study that focused on a subset of tropical Atlantic hurricanes, US Gulf land-falling hurricanes, also showed no sign of increasing hurricane frequency or intensity over the period 1886 to 1995 (Bove et al. 1998). Likewise, in regions of the northern Atlantic, there is interdecadal variation in the storm index but no century-scale increasing or decreasing trend in storm roughness in the interval 1881 to 1995 (WASA Group 1998).

A fifth important process for models to simulate is sea-ice-snow feedback (Randall et al. 1998). GCM results underpredict the variance of sea-ice thickness in the Arctic on decadal to century time scales (Battisti et al. 1997). J. Zhang et al. (1998) emphasized the importance of including realistic surface fluxes and modeling of convective overturning and vertical advection in both the Arctic and adjacent oceans, in order to reduce the over-warm intermediate layers in the Arctic Ocean and excessive heat influx into the Fram Strait predicted by models. An analysis of results from $27 \mathrm{GCM}$ s reveals that most of the models display less than half the interannual variance of snow extent; furthermore, the models underestimate snow extent in some areas and overestimate it in others (Frei \& Robinson 1998). A related consequence of sea-ice-snow feedback is sea level change, the measurements of which can be used to assess the gross state of the model results and the model's parameterization of the sea-ice-snow feedback. Fig. 9 shows satellite measurements of global sea level variations between 1993 and 1996 (Nerem et al. 1997). The reported current global rate of rise amounts to about $+2 \mathrm{~mm} \mathrm{yr}^{-1}$ (Douglas 1995, Nerem et al. 1997). The trends in rise and fall of sea level in various regions have a wide range of about $100 \mathrm{~mm} \mathrm{yr}^{-1}$, with most of the globe showing downward trends except near the eastern equatorial Pacific (Douglas 1995, Nerem et al. 1997, Leuliette \& Wahr 1999). Historical records show no acceleration in sea level rise in the 20th century (Douglas 1992). Such observations seem inconsistent with even the modest

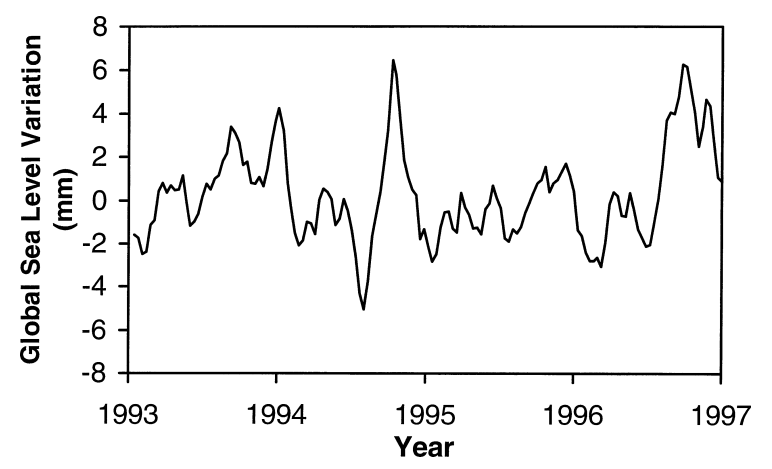

Fig. 9. Global sea level variations from the Topex/Poseidon (T/P) satellite altimeters for 1993 to 1996 (as in Fig. 1 of Nerem et al. 1997; the curve is smoothed by a $60 \mathrm{~d}$ boxcar filter and plotted for each $10 \mathrm{~d}$ cycle of the T/P altimetry). No trend is calculated here, but according to Nerem et al. (1997) the plotted T/P instrumental time series gives a 'secular' rate of change of about $-0.2 \mathrm{~mm} \mathrm{yr}^{-1}$, after the removal of annual and semi-annual variations (Nerem et al. 1997, p. 1332; see e.g. Leuliette \& Wahr 1999 for updates on the analysis of spatial and temporal variability of T/P sea surface height data). However, it has been reported that $50 \mathrm{yr}$ tide gauge measurements give $+1.8 \mathrm{~mm} \mathrm{yr}^{-1}$ (Douglas 1995). A correction of $+2.3 \mathrm{~mm}$ $\mathrm{yr}^{-1}$ was added to the satellite data, based on comparison to selected tide gauges, to obtain a value of about $+2.1 \mathrm{~mm} \mathrm{yr}^{-1}$

(Nerem et al. 1997) 
model predictions of 20th century sea level rise by oceanic thermal expansion. Predictions of $\mathrm{CO}_{2}$-induced sea level rise will likely remain uncertain for some time, because most of the factors affecting sea level change, including not only the sea-ice feedback but also vertical land motion, are not well understood and are difficult to model (Douglas 1995, Gornitz 1995, Peltier 1996, Conrad \& Hager 1997).

A sixth important set of processes to be considered in climate modeling has to do with biosphere-atmosphere-ocean feedback (Idso 1989). These processes are difficult to incorporate in models, yet progress is being made (e.g. Henderson-Sellers et al. 1996, Varejao-Silva et al. 1998). A small positive feedback effect on global temperature sensitivity has been found in a GCM that includes some effects of plant photosynthesis and soil thermodynamics (C ox et al. 1999). For latitudes above $45^{\circ} \mathrm{N}$, Levis et al. (1999) have found substantial spring and summer warming and winter cooling effects (primarily through alteration of surface albedo) when vegetation feedbacks are incorporated into a GCM under a doubled $\mathrm{CO}_{2}$ scenario. Soil moisture changes appreciably when biospheric processes are included, and including them should reduce systematic errors in the simulation of regional climate. The most important aspect of biospheric feedback is perhaps its relevance to the carbon budget of the climate system. Understanding this feedback holds the promise of an internally consistent description of the relationship of $\mathrm{CO}_{2}$ to climate change.

\section{EFFECTS OF INCREASED $\mathrm{CO}_{2}$ ON PLANTS}

Plant life provides a sink for atmospheric $\mathrm{CO}_{2}$. Using current knowledge about the increased growth rates of plants and assuming a doubling of $\mathrm{CO}_{2}$ release as compared to current emissions, it has been estimated that atmospheric $\mathrm{CO}_{2}$ levels will rise by about $300 \mathrm{ppm}$ before leveling off (Idso 1991a,b). At that level, $\mathrm{CO}_{2}$ absorption by increased terrestrial biomass may be

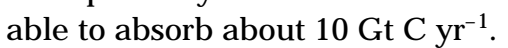

Figs. 10 to 13 show examples of experimentally measured increases in the growth of plants. These examples are representative of a very large amount of research literature on this subject (Kimball 1983, Cure \& A cock 1986, M ortensen 1987, Drake \& Leadley 1991, Lawlor \& Mitchell 1991, Gifford 1992, Poorter 1993). Since plant response to $\mathrm{CO}_{2}$ fertilization is nearly linear with respect to $\mathrm{CO}_{2}$ concentration over a range of a few hundred ppm, as seen, for example, in Figs. 10 \& 13 , it is convenient to normalize experimental measurements at different levels of $\mathrm{CO}_{2}$ enrichment. This has been done in Fig. 14a,b in order to illustrate some $\mathrm{CO}_{2}$ growth enhancements calculated for the atmos-

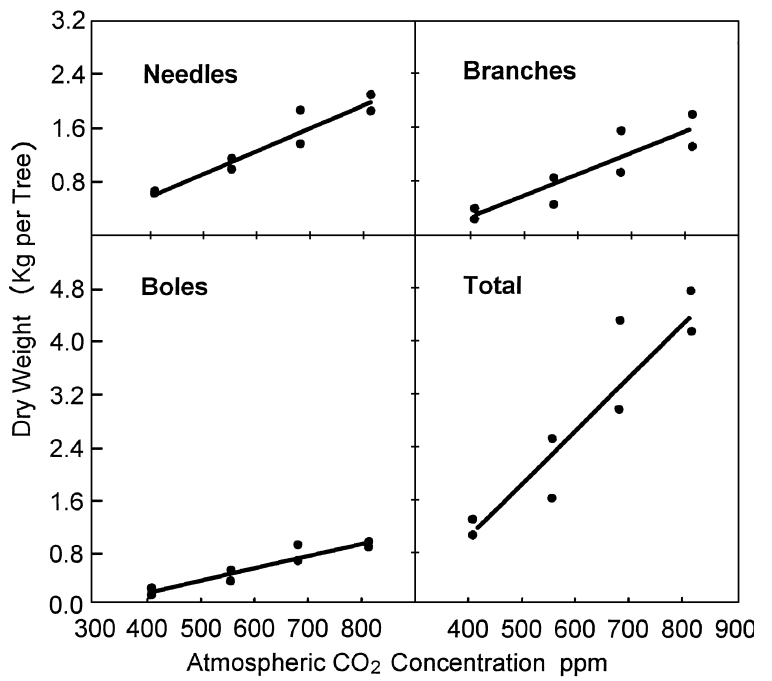

Fig. 10. Young eldarica pine trees were grown for 23 mo under $4 \mathrm{CO}_{2}$ concentrations and then cut down and weighed. Each point represents an individual tree (Idso \& Kimball 1994). Weights of tree parts are as indicated

pheric increase of about $80 \mathrm{ppm}$ that has already taken place, and that expected from a projected total increase of $320 \mathrm{ppm}$.

Fig. 10 summarizes the increased growth rates of young pine seedlings at $4 \mathrm{CO}_{2}$ levels. Again, the response is remarkable, with an increase of $300 \mathrm{ppm}$ more than tripling the rate of growth (Idso \& Kimball 1994). Fig. 11 shows the effect of $\mathrm{CO}_{2}$ fertilization on sour orange trees (Idso \& Kimball 1991, 1997). During the early years of growth, the bark, limbs, and fine roots of sour orange trees growing in an atmosphere with $700 \mathrm{ppm}$ of $\mathrm{CO}_{2}$ exhibited rates of growth more than $170 \%$ greater than those at $400 \mathrm{ppm}$. As the trees matured, this $\mathrm{CO}_{2}$-induced enhancement dropped to about $100 \%$. Meanwhile, orange production was $127 \%$ higher for the $700 \mathrm{ppm}$ trees.

Trees respond to $\mathrm{CO}_{2}$ fertilization more strongly than do most other plants, but all plants respond to some extent. Fig. 12 shows the response of wheat grown under wet conditions and when the wheat was stressed by lack of water. These were open-field experiments. Wheat was grown in the usual way, but the atmospheric $\mathrm{CO}_{2}$ concentrations of circular sections of the fields were increased by means of arrays of computercontrolled equipment that released $\mathrm{CO}_{2}$ into the air to hold the levels as specified.

While the results illustrated in Figs. 10 to 12 are remarkable, they are typical of those reported in a very large number of studies of the effects of $\mathrm{CO}_{2}$ concentration upon the growth rates of plants. Fig. 13 summarizes 279 similar experiments in which plants of various types were raised under $\mathrm{CO}_{2}$-enhanced conditions. Plants under stress from less-than-ideal conditions-a 


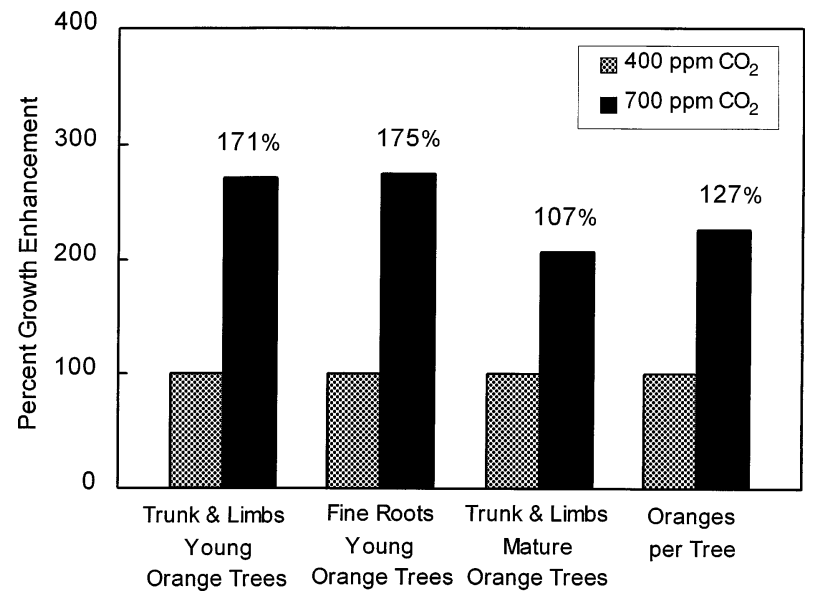

Fig. 11. Relative trunk and limb volumes and fine root biomass of young sour orange trees and trunk and limb volumes and numbers of oranges produced per mature sour orange

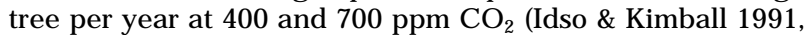
Idso \& Kimball 1997). The 400 ppm values were normalized to 100. The trees were planted in 1987 as 1 yr old seedlings. Young trunk and limb volumes and fine root biomass were measured in 1990. Mature trunk and limb volumes are averages for 1991 to 1996. Orange numbers are averages for 1993 to 1997

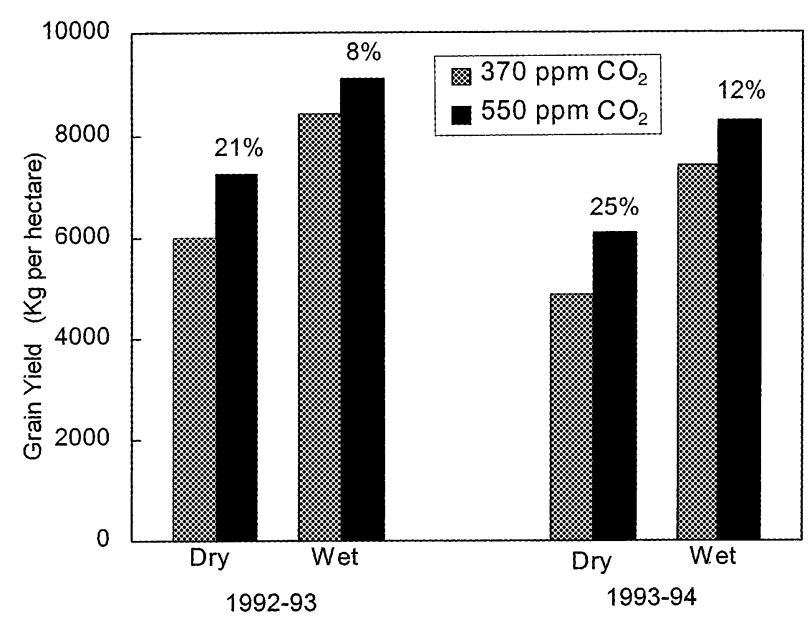

Fig. 12. Grain yields from wheat grown under well-watered and poorly watered conditions at 370 and $550 \mathrm{ppm} \mathrm{CO}_{2}$ in open-field experiments (Kimball et al. 1995, Pinter et al. 1996). Average $\mathrm{CO}_{2}$-induced increases for the 2 years were $10 \%$ for wet and $23 \%$ for dry conditions

common occurrence in nature-respond more to $\mathrm{CO}_{2}$ fertilization. The selections of species shown in Fig. 13 were biased toward plants that respond less to $\mathrm{CO}_{2}$ fertilization than does the mixture actually covering the Earth, so Fig. 13 underestimates the effects of global $\mathrm{CO}_{2}$ enhancement.

Fig. 14a,b summarize the wheat, orange tree, and young pine tree enhancements shown in Figs. 12, 11 \&

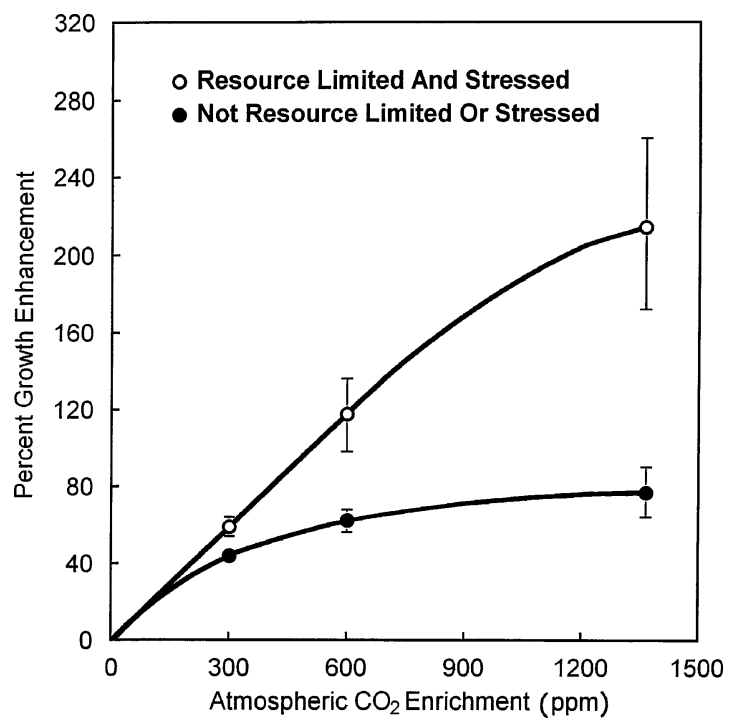

Fig. 13. Summary data from 279 published experiments in which plants of all types were grown under paired stressed and unstressed conditions (Idso \& Idso 1994). There were 208, 50 , and 21 sets of data at 300,600 , and an average of about $1350 \mathrm{ppm} \mathrm{CO}$, respectively. The plant mixture in the 279 studies was slightly biased toward plant types that respond less to $\mathrm{CO}_{2}$ fertilization than does the actual global mixture and therefore underestimates the expected global response. $\mathrm{CO}_{2}$ enrichment also allows plants to grow in drier regions, further increasing the expected global response

10 with 2 idealized atmospheric $\mathrm{CO}_{2}$ increases - that which has occurred since 1800 and is believed to be the result of the Industrial Revolution, and that which is projected for the next 2 centuries.

\section{DISCUSSION}

Calculations of the climatic impacts of increases in atmospheric $\mathrm{CO}_{2}$ concentration are not robust. Major components of the climate system are not satisfactorily represented in the models. The reason is a lack of good understanding of climate dynamics, both on theoretical and observational grounds. The models give a range of outcomes. Typically, the aggregate of various GCM s is listed as a 1.5 to $4.5^{\circ} \mathrm{C}$ global temperature rise for an approximate doubling of the atmospheric $\mathrm{CO}_{2}$ concentration (Houghton et al. 1996). The confluence of the models' outcomes and their range of changes are not to be taken as a mean and standard deviation, either statistically or physically. Given the substantial uncertanties associated with the modeling enterprise and its many parameterizations, the outcomes of the models, which are subject to large systematic errors, cannot be averaged and represented as a consensual result. 

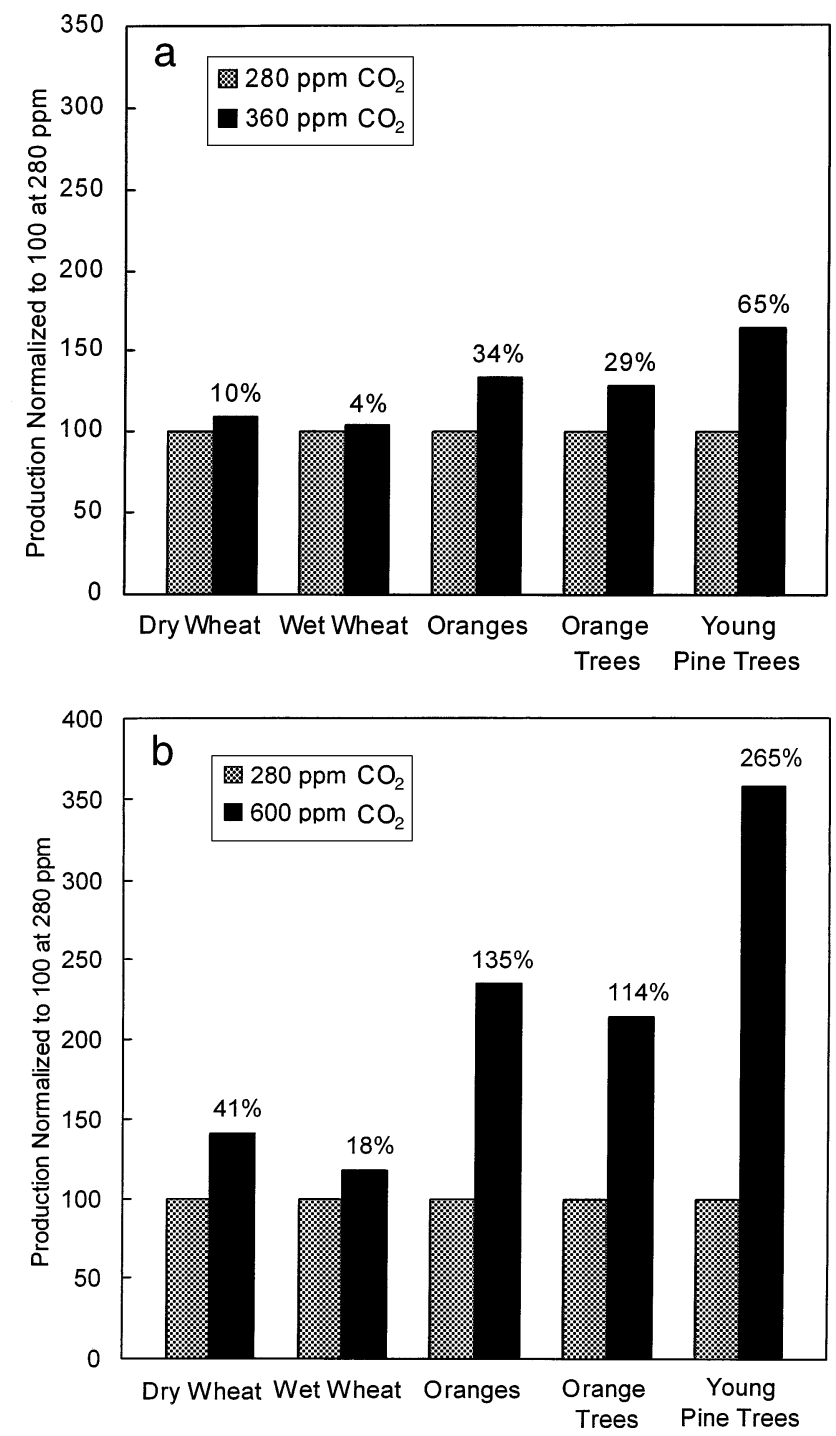

Fig. 14. (a) Calculated growth rate enhancement of wheat, young orange trees, and very young pine trees already taking place as a result of atmospheric enrichment by $\mathrm{CO}_{2}$ during the past 2 centuries. These values apply to pine trees during their first $2 \mathrm{yr}$ of growth and orange trees during their 4th through 10th years of growth. As is shown in Fig. 11, the effect of increased $\mathrm{CO}_{2}$ gradually diminishes with tree age, so these values should not be interpreted as applicable over the entire tree lifespan. There are no longer-running controlled $\mathrm{CO}_{2}$ tree experiments. (b) Calculated growth rate enhancement of wheat, young orange trees, and very young pine trees expected to take place as a result of atmospheric enrichment by $\mathrm{CO}_{2}$ to a level of $600 \mathrm{ppm}$

There are independent semi-empirical approaches that give results lying outside the consensual range of temperature change output by the models. For example, analysis of the climate response to perturbations by volcanic eruptions suggests a climate sensitivity of 0.3 to $0.5^{\circ} \mathrm{C}$ for a doubling of atmospheric $\mathrm{CO}_{2}$ (Lindzen 1997). In addition, consideration of a variety of biological and other negative feedbacks in the climate system yields a climate sensitivity of roughly $0.4^{\circ} \mathrm{C}$ for a doubling of the air's $\mathrm{CO}_{2}$ content (Idso 1998).

Taking a different approach, Forest et al. (1999) defined a probability of expected outcomes by performing a large number of sensitivity runs (i.e. by varying cloud feedback and rate of heat uptake by the deep ocean). The key statistical statement from their modelling effort is that there is a $95 \%$ probability that the expected global surface temperature increase from a doubling of the atmosphere's $\mathrm{CO}_{2}$ concentration would range from 0.5 to $3.3^{\circ} \mathrm{C}$. It may or may not be fortuitous that the semi-empirical estimates by Lindzen (1997) and Idso (1998) fall within the acceptable range of global temperature change as deduced from the statistical work of Forest et al. (1999). The result that emerges is that current climate model estimates of global temperature changes owing to increased atmospheric $\mathrm{CO}_{2}$ concentration remain highly uncertain.

\subsection{Attribution of causes of recent climatic change}

Anthropogenic global climate impacts occur against a background of natural variability. There are several limitations that impede the detection of anthropogenic effects of increased atmospheric $\mathrm{CO}_{2}$. One is the inadequacy of climate records, which are, in general, too short to capture the full range of natural variability. For example, in the case of the interpretation of the observations of the North Atlantic oscillation, time series analysis reveals a white spectrum, with little evidence of a long-term trend that might be expected from an anthropogenic signal (Wunsch 1999). Another difficulty in assessing model results for anthropogenic effects is illustrated by the fact that models underpredict the variance of natural climate change on decade to century time scales (Barnett et al. 1996, Stott \& Tett 1998), or incorrectly predict the variance (Polyak \& North 1997 [see also North 1997, Polyak 1997], Barnett 1999) on the time scale over which the anthropogenic effect of increased $\mathrm{CO}_{2}$ would be expected to arise. One reason why models underpredict natural climate change is that not all causes of natural variability have been included or have been properly parameterized in the models. A few of the suspected climate forcings that are still poorly handled in the models are volcanic eruptions (e.g. Kondratyev 1996), stratospheric ozone variations (e.g. Haigh 1999), sulfate aerosol changes (e.g. Hansen et al. 1997), and solar particle and radiative variations. The practical issue of attribution requires that such uncertainties be resolved. The radiative impact of increased atmospheric $\mathrm{CO}_{2}$ is often treated as an anomal ous and unique climatic response. 
For example, it has been claimed that anthropogenic effects are contained in recent and relatively short tropospheric temperature records (Santer et al. 1996a,b). However, this claim was shown to be unsupportable in a longer record (Michaels \& Knappenberger 1996, Weber 1996). In addition, the spatial limitations of such a record complicate the application of statistical methods used to infer correlations (Barnett et al. 1996, Legates \& Davis 1997).

The most recent comparisons of model results and observations fail to reveal a unique and significant change caused by GHG increases, sulfate aerosol changes and tropospheric as well as stratospheric ozone variations (e.g. Graf et al. 1998, Bengtsson et al. 1999). These results are consistent with analyses of northern hemisphere circulation patterns (Corti et al. 1999, Palmer 1999), in which the spatial patterns of anthropogenically forced climate change are indistinguishable from those of natural variability. Interpreting climate change under the perspective of such nonlinear dynamics imposes a strong requirement that a GCM must simulate accurately natural circulation regimes and their associated variability. This particular caveat is relevant because the global radiative forcing of a few watts per square meter as expected from combined anthropogenic GHGs is very small compared to the energy budgets of various natural components of the climate system, as well as flux errors in model parameterizations of physical processes.

\subsection{Observational outlook}

Modeling climate change is a useful approach for studying the attribution of effects of increased atmospheric $\mathrm{CO}_{2}$. However, validation of the models is essential to placing confidence in this approach. In this regard, improved observations, both in precision, accuracy, and global coverage, are important requirements. A new system of experiments, characterized by an accuracy of $0.1 \mathrm{~K}$ in thermal brightness temperature and $1 \mathrm{~cm}^{-1}$ in spectral resolution, has been proposed (Goody et al. 1998). The aim of such a system is to provide for the early detection of a relatively weak global anthropogenic signal, as well as to improve models in critical aspects.

\section{CONCLUSIONS}

At present, the unique attribution of climate change caused by radiative forcing of increased atmospheric $\mathrm{CO}_{2}$ is not possible, given the limitations of models and observed climate parameters. The use of unverified models in making future projections of incomplete (or unknown) climate forcing scenarios shifts focus from the problem of model validation. In turn, that may lead to the inconsistency of working with a $\mathrm{CO}_{2}$ global warming hypothesis that is not falsifiable. Further, impact assessments, like sea level rise or altered frequencies and intensities of storms, are premature. In addition, there is no clear evidence of the modelexpected anthropogenic $\mathrm{CO}_{2}$ global effect on climate, either in surface temperature records of the last $100 \mathrm{yr}$, or in tropospheric temperature records obtained from balloon radiosondes over the last $40 \mathrm{yr}$, or in tropospheric temperature records obtained from MSU satellite experiments over the last $20 \mathrm{yr}$. There is, however, substantial evidence for a host of beneficial effects of increased atmospheric $\mathrm{CO}_{2}$ on plant growth and development.

Acknowledgements. We are grateful to Sherwood Idso for his illuminating advice and comments on this paper. This work was supported by the M assachusetts Space Grant Consortium (MIT grant 16717049) and the National Aeronautics and Space Administration (grant NAG5-7635).

\section{LITERATURE CITED}

Angell JK (1997) Annual and seasonal global temperature anomalies in the troposphere and low stratosphere, 1958-1996. In: Trends online: a compendium of data on global change, Oak Ridge National Laboratory Oak Ridge, TN. Available at http://cdiac.esd.ornl.gov/ftp/ ndp008/; additional updates in ftp://gus.arlhq.noaa.gov/ pub/climate/angell_anoms/temperature/layer-mean/L850300.txt

Balling RC J r (1992) The heated debate. Pacific Research Institute, San Francisco

Barnett TP (1999) Comparison of near-surface air temperature variability in 11 coupled global climate models. J Clim 12: 511-518

Barnett TP, Santer BD, J ones PD, Bradley RS, Briffa KR (1996) Estimates of low frequency natural variability in nearsurface air temperature. Holocene 6:255-263

Battisti DS, Bitz CM, M oritz RE (1997) Do general circulation models underestimate the natural variability in the Arctic climate? J Clim 10:1909-1920

Bengtsson L, Roeckner E, Stendel M (1999) Why is the global warming proceeding much slower than expected? J Geophys Res 104:3865-3876

Berner RA (1997) The rise of plants and their effect on weathering and atmospheric $\mathrm{CO}_{2}$. Science 276:544-545

Böhm R (1998) Urban bias in temperature time series - a case study for the city of Vienna, Austria. Clim Change 38: 113-128

Bove M C, Zierden DF, O'Brien JJ (1998) Are Gulf landfalling hurricanes getting stronger? Bull Am Meteorol Soc 79: 1327-1328

Boyle J S (1998) Intercomparison of interannual variability of the global 200-hPa circulation for AMIP simulations. J Clim 11:2505-2529

Bradley RS, J ones PD (1993) 'Little Ice Age' summer temperature variations: their nature and relevance to recent global warming trends. Holocene 3:367-376 
Briffa KR and 7 others (1998) Trees tell of past climates: but are they speaking less clearly today? Philos Trans R Soc Lond Ser B Biol Sci 353:65-73

Broccoli AJ, Lau NC, Nath MJ (1998) The cold ocean-warm land pattern: model simulation and relevance to climate change detection. J Clim 11:2743-2763

Brown WO, Heim RR (1998) National Climate Data Center, Climate Variations Bulletin Volume 10 , Number 12 , Historical Climatology Series; Available at http://www.ncdc. noaa.gov/ol/documentlibrary/cvb.html

Cai WJ, Gordon HB (1999) Southern high-latitude ocean climate drift in a coupled model. J Clim 12:132-146

Cess RD and 19 others (1995) A bsorption of solar radiation by clouds: observations versus models. Science 267:496-499

Cess RD and 35 others (1997) Comparison of the seasonal change in cloud-radiative forcing from atmospheric general circulation models and satellite observations. J Geophys Res 102:16593-16603

Cess RD and 7 others (1999) Absorption of solar radiation by the cloudy atmosphere: further interpretations of collocated aircraft measurements. J Geophys Res 104: 2059-2066

Charlock TP, Alberta TL (1996) The CERES/ARM/GEWEX experiment for the retrieval of radiative fluxes with satellite data. Bull Amer M eteorol Soc 77:2673-2683

Chou C, Neelin J D (1999) Cirrus detrainment-temperature feedback. Geophys Res Lett 26:1295-1298

Christy J R (1995) Temperature above the surface layer. Clim Change 31:455-474

Christy J R (1997) Evidence from the satellite record. In: J ones $\mathrm{L}$ (ed) Global warming - the science and the politics. The Fraser Institute, Vancouver, p 55-75

Christy J R, Goodridge JD (1995) Precision global temperatures from satellites and urban warming effects of nonsatellite data. Atmos Environ 29:1957-1961

Christy J R, McNider RT (1994) Satellite greenhouse signal. Nature 367:325

Christy J R, Spencer RW, Lobl ES (1998) Analysis of the merging procedure for the MSU daily temperature time series. J Clim 11:2016-2041 (Data available at ftp://wind.atmos. uah.edu/msu/t21t)

CRU (Climate Research Unit) (1999) Temperature. CRU, East Anglia University, Norwich. Available at http://www.cru. uea.ac.uk/cru/data/temperat.htm

Conrad CP, Hager BH (1997) Spatial variations in the rate of sea level rise caused by the present-day melting of glaciers and ice sheets. Geophys Res Lett 24:1503-1506

Corti S, M olteni F, Palmer TN (1999) Signature of recent climate change in frequencies of natural atmospheric circulation regimes. Nature 398:799-802

Cox PM and 5 others (1999) The impact of new land surface physics of the GCM simulation of climate and climate sensitivity. Clim Dyn 15:183-203

Cure J D, Acock B (1986) Crop responses to carbon dioxide doubling: a literature survey. Agric For Meteorol 8: 127-145

Dettinger DM, Ghil M (1998) Seasonal and interannual variations of atmospheric $\mathrm{CO}_{2}$ and climate. Tellus 50B:1-24

Douglas BC (1992) Global sea level acceleration. J Geophys Res 97:12699-12706

Douglas BC (1995) Global sea level change: determination and interpretation. Rev Geophys Suppl:1425-1432

Drake BG, Leadley PW (1991) Canopy photosynthesis of crops and native plant communities exposed to long-term elevated $\mathrm{CO}_{2}$. Plant Cell Environ 14:853-860

Fischer H, Wahlen M, Smith J, Mastroianni D, Deck B (1999) Ice core records of atmospheric $\mathrm{CO}_{2}$ around the last three glacial terminations. Science 283:1712-1714

Forest CE, Allen M R, Stone PH, Sokolov AP (1999) Constraining uncertainties in climate models using climate change detection technique. MIT J oint Program on the Science and Policy of Global Change Publication: Report no. 47. Available at http://web.mit.edu/globalchange/www/reports. html

Fowler LD, Randall DA (1999) Simulation of upper tropospheric clouds with the Colorado State University general circulation model. J Geophys Res 104:6101-6121

Frei A, Robinson DA (1998) Evaluation of snow extent and its variability in the A tmospheric M odel Intercomparison Project. J Geophys Res 103:8859-8871

Gaffen DJ , Rosen RD, Salstein DA, Boyle J S (1997) Evaluation of tropospheric water vapor simulations from Atmospheric M odel Intercomparison Project. J Clim 10:1848-1661

Gallo KP, Owen TW, Easterling DR, J amason PF (1999) Temperature trends of the U.S. Historical Climatology Network based on satellite-designated land use/land cover. J Clim 12:1344-1348

Gifford RM (1992) Interaction of carbon dioxide with growthlimiting environmental factors in vegetative productivity: implications for the global carbon cycle. Adv Bioclim 1: 24-58

Glecker PJ , Weare BC (1997) Uncertainties in global ocean surface heat flux climatologies derived from ship observations. J Clim 10:2764-2781

Glecker PJ and 15 others (1995) Cloud-radiative effects on implied oceanic energy transports as simulated by atmospheric general circulation models. Geophys Res Lett 22: 791-794

Godfrey JS and 6 others (1998) Coupled Ocean-Atmosphere Response Experiment (COARE): an interim report. J Geophys Res 103:14395-14450

Goodridge JD (1996) Comments on regional simulations of greenhouse warming including natural variability. Bull Am M eteorol Soc 77:3-4

Goody R, Anderson J , North G (1998) Testing climate models: an approach. Bull Am M eteorol Soc 79:2541-2549

Gornitz V (1995) M onitoring sea level changes. Clim Change 31:515-544

Graf HF, Kirchner I, Perlwitz J (1998) Changing lower stratospheric circulation: the role of ozone and greenhouse gases. J Geophys Res 103:11251-11261

Grove J M, Switsur R (1994) Glacial geological evidence for the medieval warm period. Clim Change 26:143-169

Grove J M (1996) The century time-scale. In: Driver TS, Chapman GP (eds) Time-scales and environmental change. Routledge, London, p 39-87

Hahn CJ , Warren SG, London J (1996) Edited synoptic cloud reports from ships and land stations over the globe, 1982-1991. Tech Rep NDP-026b Carbon Dioxide Information Analysis Center, Oak Ridge National Laboratory, Oak Ridge, TN. Available at http://cdiac.esd.ornl.gov/ epubs/ndp/ndp026b.htm

Haigh J D (1999) A GCM study of climate change in response to the 11-year solar cycle. Q J R M eteorol Soc 125:871-892

Hansen J , Lebedeff S (1987) Global trends of measured surface air temperature. J Geophys Res 92:13345-13372

Hansen J, Lebedeff S (1988) Global surface air temperature: update through 1987. Geophys Res Lett 15:323-326

Hansen J , Ruedy R, Sato M, Reynolds R (1996) Global surface air temperature in 1995; return to pre-Pinatubo level. Geophys Res Lett 23:1665-1668 (Data available at http:// www.giss.nasa.gov/data/gistemp/GLB.Ts.txt)

Hansen J, Sato M, Ruedy R (1997) Radiative forcing and climate response. J Geophys Res 102:6831-6864 
Henderson-Sellers A, McGuffie K, Pitman A (1996) The project for intercomparison of land-surface parameterizaion schemes (PILPS); 1992-1995. Clim Dyn 12:849-859

Henderson-Sellers A and 10 others (1998) Tropical cyclones and global climate change: a post-IPCC assessment. Bull Am Meteorol Soc 79:19-38

Houghton J T, Merra Filho LG, Callendar BA, Harris N, Kattenberg A, Maskell K (eds) (1996) Climatic change 1995: the science of climate change: contribution of working group I to the second assessment. Report of the intergovernmental panel on climate change. Cambridge University Press, Cambridge

Houghton RA, Davidson EA, Woodwell GM (1998) Missing sinks, feedbacks, and understanding the role of terrestrial ecosystems in the global carbon balance. Global Biogeochem Cycles 12:25-34

$\mathrm{Hu} \mathrm{H}$, Liu WT (1998) The impact of upper tropospheric humidity from Microwave Limb Sounder on the midlatitude greenhouse effect. Geophys Res Lett 25: 3151-3154

Hughes MK, Diaz HF (1994) Was there a 'Medieval warm period', and if so, where and when? Clim Change 26: $109-142$

Idso KE, Idso SB (1994) Plant responses to atmospheric $\mathrm{CO}_{2}$ enrichment in the face of environmental constraints: a review of the past 10 years' research. Agric For M eteorol 69:153-203

Idso SB (1989) Carbon dioxide and global change: earth in transition. IBR Press, Tempe, AZ

Idso SB (1991a) The aerial fertilization effect of $\mathrm{CO}_{2}$ and its implications for global carbon cycling and maximum greenhouse warming. Bull Am Meteorol Soc 72:962-965

Idso SB (1991b) Reply to comments of L. D. Danny Harvey, B. Bolin, and P. Lehmann. Bull Am Meteorol Soc 72: 1910-1914

Idso SB (1998) $\mathrm{CO}_{2}$-induced global warming: a skeptic's view of potential climate change. Clim Res 10:69-82

Idso SB, Kimball BA (1991) Effects of two and a half years of atmospheric $\mathrm{CO}_{2}$ enrichment on the root density distribution of three year-old sour orange trees. Agric For M eteorol 55:345-349

Idso SB, Kimball BA (1994) Effects of atmospheric $\mathrm{CO}_{2}$ enrichment on biomass accumulation and distribution in Eldarica pine trees. J Exp Bot 45:1669-1692

Idso SB, Kimball BA (1997) Effects of long-term atmospheric $\mathrm{CO}_{2}$ enrichment on the growth and fruit production of sour orange trees. Global Change Biol 3:89-96

Inamdar AK, Ramanathan V (1998) Tropical and global scale interactions among water vapor, atmospheric greenhouse effect, and surface temperature. J Geophys Res 103: 32177-32194

Indermühle A and 11 others (1999) Holocene carbon-cycle dynamics based on $\mathrm{CO}_{2}$ trapped in ice at Taylor Dome, Antarctica. Nature 398:121-126

J ain S, Lall U, Mann ME (1999) Seasonality and interannual variations of northern hemisphere temperature: equatorto-pole and ocean-land contrast. J Clim 12:1086-1100

J ones PD, Osborn TJ , Briffa KR (1997) Estimating sampling errors in large-scale temperature averages. J Clim 10: 2548-2568

Karl TR, Knight RW, Christy J R (1994) Global and hemispheric temperature trends: uncertainties related to inadequate spatial sampling. J Clim 7:1144-1163

Keeling CD, Whorf TP (1997) Atmospheric $\mathrm{CO}_{2}$ concentrations-M auna Loa observatory, Hawaii. In: Trends online: a compendium of data on global change. Carbon Dioxide Information Analysis Center, Oak Ridge National Labora- tory, Oak Ridge, TN. Available at http://cdiac.esd.ornl. gov/ftp/ndp00/

Keeling RF, Manning AC, McEvoy EM, Shertz SR (1998) $M$ ethods for measuring changes in atmospheric $\mathrm{CO}_{2}$ concentration and their application in southern hemisphere air. J Geophys Res 103:3381-3397

Keigwin LD (1996) The little ice age and medieval warm period in the Sargasso Sea. Science 274:1504-1508

Kimball BA (1983) Carbon dioxide and agricultural yield: an assemblage and analysis of 430 prior observations. Agron J 75:779-788

Kimball BA and 8 others (1995) Productivity and water use of wheat under free-air $\mathrm{CO}_{2}$ enrichment. Global Change Biol 1:429-442

Knutson TR, Tuleya RE, Kurihara Y (1998) Simulated increase of hurricane intensities in a $\mathrm{CO}_{2}$-warmed climate. Science 279:1018-1020

Kondratyev KYa (1996) Volcanic eruptions and climate change. In: Fiocco G, Fua D, Visconti G (eds) The M ount Pinatubo eruption's effects on the atmosphere and climate. NATO ASI series 142, Springer-Verlag, Berlin, p 273-287

Kuo C, Lindberg CR, Thomson DJ (1990) Coherence established between atmospheric carbon dioxide and global temperature. Nature 343:709-714

Lamb HH (1982) Climate, history, and the modern world. Methuen, New York

Landsea CW, Nicholls N, Gray WM, Avila LA (1996) Downward trends in the frequency of intense Atlantic hurricanes during the past five decades. Geophys Res Lett 23: 1697-1700

Lawlor DW, Mitchell RAC (1991) The effects of increasing $\mathrm{CO}_{2}$ on crop photosynthesis and productivity: a review of field studies. Plant Cell Environ 14:807-818

Legates DR, Davis RE (1997) The continuing search for an anthropogenic climate change signal: limitations of correlation-based approaches. Geophys Res Lett 24:2319-2322

Leuliette EW, Wahr J M (1999) Coupled pattern analysis of sea surface temperature and TOPEX/Poseidon sea surface height. J Phys Oceanogr 29:599-611

Levis S, Foley J A, Pollard D (1999) Potential high-latitude vegetation feedbacks on $\mathrm{CO}_{2}$-induced climate change. Geophys Res Lett 26:741-750

Li Z, M oreau L, Arking A (1997) On solar energy deposition: a perspective from observation and modeling. Bull Am Meteorol Soc 78:53-70

Liao X, Rind D (1997) Local upper tropospheric/lower stratospheric clear-sky water vapor and tropospheric deep convection. J Geophys Res 102:19543-19557

Lindzen RS (1997) Can increasing carbon dioxide cause climate change? Proc Natl Acad Sci USA 94:8335-8342

Madden RA, Shea DJ , Banstator GW, Tribbia J J , Weber RO (1993) The effects of imperfect spatial and temporal sampling on estimates of the global mean temperature: experiments with model data. J Clim 6:1057-1066

Mann ME, Bradley RS, Hughes MK (1999) Northern hemisphere temperatures during the past millennium: inferences, uncertainties, and limitations. Geophys Res Lett 26: 759-762

M arland G, Andres RJ , Boden TA, J ohnston CA, Brenkert AL (1999) Global, regional, and national $\mathrm{CO}_{2}$ emission estimates from fossil fuel burning, cement production, and gas flaring: 1751-1996. In: trends online: a compendium of data on global change. Oak Ridge National Laboratory, Oak Ridge, TN. Available at http://cdiac.esd.ornl.gov/ $\mathrm{ftp} / \mathrm{ndp030}$

Mason BJ (1995) Predictions of climate changes caused by 
man-made emissions of greenhouse gases: a critical assessment. Contemp Phys 36:299-319

Michaels PJ, Knappenberger PC (1996) Human effect on global climate? Nature 384:522-523

Michaels PJ, Balling RC J r, Vose RS, Knappenberger PC (1998) Analysis of trends in the variability of daily and monthly historical temperature measurements. Clim Res 10:15-26

Mortensen LM (1987) Review: $\mathrm{CO}_{2}$ enrichment in greenhouses. Sci Hortic 33:1-25

Murphy J M (1995) Transient response of the Hadley Centre coupled ocean-atmosphere model to increasing carbon dioxide. Part I: control climate and flux adjustment. J Clim 8:36-56

Nerem RS and 5 others (1997) Improved determination of global mean sea level variations using Topex/Poseidon altimeter data. Geophys Res Lett 24:1331-1334

North GR (1997) Comment on 'Evaluation of the GFDL GCM climate variability, 2. Stochastic modeling and latitudetemporal fields' by I. Polyak and G. R. North. J Geophys Res 102:30161

Palmer TN (1999) A nonlinear dynamical perspective on climate change. J Clim 12:575-591

Parker DE, J ones PD, Bevan A, Folland CK (1994) Interdecadal changes of surface temperature since the late $19^{\text {th }}$ century. J Geophys Res 99:14373-14399

Parker DE and 5 others (1997) A new global gridded radiosonde temperature data base and recent temperature trends. Geophys Res Lett 24:1499-1502

Peltier WR (1996) Global sea level rise and glacial isostatic adjustment: an analysis of data from the east coast of North America. Geophys Res Lett 23:717-720

Peng HF, Wanninkhof R, Feely RA, Takahashi T (1998) Quantification of decadal anthropogenic $\mathrm{CO}_{2}$ uptake in the ocean based on dissolved inorganic carbon measurements. Nature 396:560-563

Peterson TC and 5 others (1999) Global rural temperature trends. Geophys Res Lett 26:329-332

Pinter JP J r and 5 others (1996) Free-air $\mathrm{CO}_{2}$ enrichment: responses of cotton and wheat crops. In: Koch GW, Mooney HA (eds) Carbon dioxide and terrestrial ecosystems. Academic Press, San Diego, CA, p 215-249

Polyak I (1997) Reply. J Geophys Res 102:30162

Polyak I, North G (1997) Evaluation of the GFDL GCM climate variability. 2. Stochastic modeling and latitudetemporal fields. J Geophys Res 102:6799-6812

Poorter H (1993) Interspecific variation in the growth response of plants to an elevated ambient $\mathrm{CO}_{2}$ concentration. Vegetatio 104-105:77-97

Priem HA (1997) $\mathrm{CO}_{2}$ and climate: a geologist's view. Space Sci Rev 81:173-198

Randall D and 9 others (1998) Status of and outlook for largescale modeling of atmospheric-ice-ocean interactions in the Arctic. Bull Am M eteorol Soc 79:197-219

Renno NO, Emanuel KA, Stone PH (1994) Radiative-convective model with an explicit hydrologic cycle. J Geophys Res 99:14429-14441

Robeson SM (1995) Resampling of network-induced variability in estimates of terrestrial air temperature change. Clim Change 29:213-229

Ross RJ , Gaffen DJ (1998) Comment on 'Widespread tropical atmospheric drying from 1979 to 1995 ' by Schroeder and McGuirk. Geophys Res Lett 25:4357-4358

Rossow WB, Cairns B (1995) Monitoring changes of clouds. Clim Change 31:305-347

Rotstayn LD (1999) Climate sensitivity of the CSIRO GCM: effect of cloud modeling assumptions. J Clim 12:334-356
Santer BD and 12 others (1996a) A search for human influences on the thermal structure of the atmosphere. Nature 382:39-46

Santer BD and 13 others (1996b) Reply. Nature 384:524

Schimel DS (1995) Terrestrial ecosystems and the carbon cycle. Global Change Biol 1:77-91

Schneider SH (1994) Detecting climate change signals: are there any 'fingerprints?' Science 263:341-347

Schroeder SR, McGuirk JP (1998a) Widespread tropical atmospheric drying from 1979 to 1995 . Geophys Res Lett 25:1301-1304

Schroeder SR, M cGuirk J P (1998b) Reply to Ross and Gaffen 1998. Geophys Res Lett 25:4359-4360

Segalstad TV (1998) Carbon cycle modeling and the residence time of natural and anthropogenic atmospheric $\mathrm{CO}_{2}$ : on the construction of the 'greenhouse effect global warming' dogma. In: Bate R (ed) Global warming the continuing debate. European Science and Environmental Forum, Cambridge, p 184-218

Senior CA (1999) Comparison of mechanisms of cloud-climate feedbacks in GCM s. J Clim 12:1480-1489

Siegel DA, Westberry TK, OhImann JC (1999) Cloud color and ocean radiant heating. J Clim 12:1101-1116

Simmons A J, Untch A, J akob C, Kallberg P, Unden P (1999) Stratospheric water vapor and tropical tropopause temperatures in ECMWF analyses and multiyear simulations. Q J R M eteorol Soc 125:353-386

Soden BJ (1997) Variations in the tropical greenhouse effect during El Niño. J Clim 10:1050-1055

Spencer RW, Braswell WD (1997) How dry is the tropical free troposphere? Implications for global warming theory. Bull Am M eteorol Soc 78:1097-1106

Spencer RW, Christy J R (1990) Precise monitoring of global temperature trends from satellites. Science 247: 1558-1562

Spencer RW, Christy J R (1992) Precision and radiosonde validation of satellite gridpoint temperature anomalies. part I: MSU channel 2 and part II: a tropospheric retrieval and trends during 1979-1990. J Clim 5:847-866

Spencer RW, Christy J R, Grody NC (1990) Global atmospheric temperature monitoring with satellite microwave measurements: method and results 1979-1984. J Clim 3: 1111-1128

Stooksbury DE, Idso CD, Hubbard KG (1999) The effects of data gaps on the calculated monthly mean maximum and minimum temperatures in the continental United States: a spatial and temporal study. J Clim 12:1524-1533

Stott PA, Tett SFB (1998) Scale-dependent detection of climate change. J Clim 11:3282-3294

Sun DZ, Held IM (1996) A comparison of modeled and observed relationships between interannual variations of water vapor and temperature. J Clim 9:665-675

Trenberth KE, Christy J R, Hurrell J W (1992) Monitoring global monthly mean surface temperatures. J Clim 5: 1405-1423

Valero FPJ and 7 others (1997a) Atmospheric Radiation M easurements Enhanced Shortwave Experiment (ARESE): experimental and data details. J Geophys Res 102: 29929-29937

Valero FPJ and 6 others (1997b) Absorption of solar radiation by the cloudy atmosphere: interpretations of collocated aircraft measurements. J Geophys Res 102: 29917-29927

Varejao-Silva MA, Franchito SH, Rao VB (1998) A coupled biosphere-atmosphere climate model suitable for studies of climatic change due to land surface alterations. J Clim 11:1749-1767 
Wallace J M, Zhang Y, Renwick J A (1995) Dynamic contribution to hemispheric mean temperature trends. Science 270:780-783

Wallace J M, Zhang Y, Bajuk L (1996) Interpretation of interdecadal trends in northern hemisphere surface air temperature. J Clim 9:249-259

WASA Group (1998) Changing waves and storms in the Northeast Atlantic? Bull Am Meteorol Soc 79:741-760

Weber GO (1996) Human effect on global climate? Nature 384:523-524

Weare BC (1999) Combined satellite- and surface-based observations of clouds. J Clim 12:897-913

Weare BC, AMIP M odeling Groups (1996) Evaluation of the vertical structure of zonally averaged cloudiness and its variability in the Atmospheric M odel Intercomparison Project. J Clim 9:3419-3431

Wentz FJ , Schabel M (1998) Effects of orbital decay on satellite-derived lower-tropospheric temperature trends. Nature 394:661-664

Wild M, Ohmura A, Gilgen H, Roeckner E (1995) Validation of GCM simulated radiative fluxes using surface observations. J Clim 8:1309-1324

Wild M, Ohmura A, Gilgen H, M orcrette JJ (1998) The distribution of solar energy at the Earth's surface as calculated in the ECMWF re-analysis. Geophys Res Lett 25: 4373-4376

Wunsch C (1999) The interpretation of short climate records,

Editorial responsibility: Chris de Freitas,

Auckland, New Zealand with comments on the North Atlantic and Southern Oscillation. Bull Am M eteorol Soc 79:245-255

Wylie DP, Menzel WP (1999) Eight years of high cloud statistics using HIRS. J Clim 12:170-184

Yang H, Tung KK (1998) Water vapor, surface temperature, and the greenhouse effect-a statistical analysis of tropical-mean data. J Clim 11:2686-2697

Yao MS, Del Genio AD (1999) Effects of cloud parameterization on the simulation of climate changes in the GISS GCM . J Clim 12:761-779

Yu JY, M echoso CR (1999) A discussion on the errors in the surface heat fluxes simulated by a coupled GCM. J Clim $12: 416-426$

Zender CS and 7 others (1997) Atmospheric absorption during the Atmospheric Radiation Measurement (ARM) Enhanced Shortwave Experiment (ARESE). J Geophys Res 102:29901-29915

Zhang J , Hibler WD III, Steele M, Rothrock DA (1998) Arctic ice-ocean modeling with and without climate restoring. J Phys Oceanogr 28:191-217

Zhang MH, Lin WY, Kiehl JT (1998) Bias of atmospheric shortwave absorption in the NCAR Community Climate Models 2 and 3: comparison with monthly ERBE/GEBA measurements. J Geophys Res 103:8919-8925

Zwiers FW, Kharin VV (1998) Changes in extremes of the climate simulated by CCC GCM2 under $\mathrm{CO}_{2}$ doubling. J Clim 11:2200-2222

Submitted: A pril 28, 1998; Accepted: J uly 1, 1999

Proofs received from author(s): September 8, 1999 